\title{
PERKEMBANGAN BAHASA ANAK
}

\author{
Evi Hasim \\ Dosen Pendidikan Guru Sekolah Dasar \\ Universitas Negeri Gorontalo
}

\begin{abstract}
ABSTRAK
Bahasa merupakan suatu alat komunikasi yang disampaikan seseorang kepada orang lain agar bisa mengetahui apa yang menjadi maksud dan tujuannya. Pentingnya bahasa sebagai identitas manusia, tidak bisa dilepaskan dari adanya pengakuan manusia terhadap pemakaian bahasa dalam kehidupan bermasyarakat sehari-hari. Untuk menjalankan tugas kemanusiaan, manusia hanya punya satu alat, yakni bahasa. Dengan bahasa, manusia dapat mengungkapkan apa yang ada di benak mereka. Sesuatu yang sudah dirasakan sama dan serupa dengannya, belum tentu terasa serupa, karena belum terungkap dan diungkapkan. Hanya dengan bahasa, manusia dapat membuat sesuatu terasa nyata dan terungkap.
\end{abstract}

Kata Kunci : Perkembangan, Bahasa Anak

\section{A.PENDAHULUAN}

Perkembangan merupakan

suatu perubahan yang berlangsung seumur hidup dengan bertambahnya struktur dan fungsi tubuh yang lebih kompleks dalam kemampuan gerak kasar, gerak halus, bicara dan bahasa serta sosialisasi dan kemandirian. Ciri-ciri pertumbuhan dan perkembangan anak antara lain, menimbulkan perubahan, berkolerasi dengan pertumbuhan, memiliki tahap yang berurutan dan mempunyai pola yang tetap.
Masa bayi atau balita (dibawah lima tahun) adalah masa yang paling signifikan dalam kehidupan manusia. Seorang bayi dari hari ke hari akan mengalami perkembangan bahasa dan kemampuan bicara, namun tentunya tiap anak tidak sama persis pencapaiannya, ada yang cepat berbicara ada pula yang membutuhkan waktu agak lama. Untuk membantu perkembangannya, ibu dapat membantu memberikan stimulasi yang disesuaikan dengan keunikan masing-masing anak. 
PEDAGOGIKA

Jurnal Ilmu Pendidikan

Volume 9 (Nomor 2) 2018

Sejalan dengan perkembangan

diutarakan dalam bentuk lisan, kemampuan serta kematangan jasmani terutama yang bertalian dengan proses bicara, komunikasi tersebut makin meningkat dan meluas.

Bahasa merupakan suatu alat komunikasi yang disampaikan seseorang kepada orang lain agar bisa mengetahui apa yang menjadi maksud dan tujuannya. Pentingnya bahasa sebagai identitas manusia, tidak bisa dilepaskan dari adanya pengakuan manusia terhadap pemakaian bahasa dalam kehidupan bermasyarakat sehari-hari. Untuk menjalankan tugas kemanusiaan, manusia hanya punya satu alat, yakni bahasa. Dengan bahasa, manusia dapat mengungkapkan apa yang ada di benak mereka. Sesuatu yang sudah dirasakan sama dan serupa dengannya, belum tentu terasa serupa, karena belum terungkap dan diungkapkan. Hanya dengan bahasa, manusia dapat membuat sesuatu terasa nyata dan terungkap. tulisan, bahasa isyarat, bahasa gerak tubuh, ekspresi wajah pantomim atau seni. Sedangkan bicara adalah bahasa lisan yang merupakan bentuk yang paling efektif untuk berkomunikasi, dan paling penting serta paling banyak dipergunakan. Perkembangan bahasa tersebut selalu meningkat sesuai dengan meningkatnya usia anak. Orang tua sebaiknya selalu memperhatikan perkembangan tersebut, sebab pada masa ini, sangat menentukan proses belajar. Hal ini dapat dilakukan dengan memberi contoh yang baik, memberikan motivasi pada anak untuk belajar dan sebagainya.

Perkembangan bahasa pada anak sangatlah bertahap yang di bagi dalam beberapa bagian yang akan bahas dalam makalah ini. Oleh karena itu penulis sengaja mengangkat tema yang berkaitan dengan peerkembangan bahasa pada manusia khusunya pada anak-anak yaitu "Perkembangan Bahasa Anak".

Terdapat perbedaan yang signifikan antara pengertian bahasa dan berbicara. Bahasa mencakup segala bentuk komunikasi, baik yang

\section{B.KAJIAN TEORI}

Pedagogika.fup@ung.ac.id P-ISSN : 2086-4469 E-ISSN : 2716-0580 
PEDAGOGIKA

Jurnal Ilmu Pendidikan

Volume 9 (Nomor 2) 2018

\section{Pengertian}

Perkembangan

\section{Bahasa}

Bahasa adalah yang terpadu dengan unsur-unsur lain didalam jaringan kebudayaan. Pada waktu yang sama, bahasa merupakan sarana pengungkapan nilai-nilai budaya. Pikiran dan nilai-nilai kehidupan kemasyarakatan. Perkembangan kebudayaan Indonesia kearah peradaban modern sejalan dengan kemajuan dan perkembangan ilmu pengetahuan dan teknologi menuntut adanya perkembangan cara berpikir yang ditandai oleh kecermatan, ketepatan, dan kesanggupan menyatakan isi pikiran secara eksplisit.

\section{Perkembangan}

bahasa

merupakan kemampuan khas manusia yang paling kompleks dan mengagumkan.Kemampuan

berbahasa anak tidak diperoleh secara tiba-tiba atau sekaligus, tetapi bertahap.Kemajuan berbahasa mereka berjalan seiring dengan perkembangan fisik, mental, intelektual, dan sosialnya.Perkembangan bahasa anak ditandai oleh keseimbangan dinamis atau suatu rangkaian kesatuan yang bergerak dari bunyi-bunyi atau ucapan yang sederhana menuju tuturan yang lebih kompleks.

\section{Tahap-tahap Perkembangan Bahasa Anak}

Tahapan perkembangan bahasa anak dapat dibagi atas:

1) Tahap Pralingustik (0 - 12 bulan)

Sebelum mampu mengucapkan suatu kata, bayi mulai memperoleh bahasa ketika berumur kurang dari satu tahun.Namun pada tahap ini, bunyi-bunyi bahasa yang dihasilkan anak belumlah bermakna.Bunyi-bunyi itu berupa vokal atau konsonan tertentu tetapi tidak mengacu pada kata atau makna tertentu. Untuk itulah sehingga perkembangan bahasa anak pada masa ini disebut tahap pralinguistik (Tarigan, 1988; Tarigan dkk., 1998; Ellies dkk.,1989). Bahkan pada awalnya, bayi hanya mampu mengeluarkan suara yaitu tangisan.Pada umumnya orang mengatakan bahwa bila bayi yang baru lahir menangis, menandakan bahwa bayi tersebut merasa lapar, 
PEDAGOGIKA

Jurnal Ilmu Pendidikan

Volume 9 (Nomor 2) 2018

takut, atau bosan. Sebenarnya tidak hanya itu saja terjadi.

Para peneliti perkembangan mengatakan bahwa lingkungan memberikan mereka halangan tentang apa yang dirasakan oleh bayi, bahkan tangisan itu sudah mempunyai nilai komunikatif. Bayi yang berusia $4-7$ bulan biasanya sudah mulai mengahasilkan banyak suara baru yang menyebabkan masa ini disebut masa ekspansi (Dworetzky, 1990). Suara-suara baru itu meliputi: bisikan, menggeram, dan memekik. Setelah memasuki usia 7 - 12 bulan, ocehan bayi meningkat pesat dikenal dengan masa connical.

2) Tahap Satu-Kata (12 - 18 bulan)

Pada masa ini, anak sudah mulai belajar menggunakan satu kata yang memiliki arti yang mewakili keseluruhan idenya.Satu-kata mewakili satu atau bahkan lebih frase atau kalimat.Kata-kata pertama yang lazim diucapkan berhubungan dengan objek-objeknyata atau perbuatan.Kata-kata yang sering diucapkan orang tua sewaktu mengajak bayinya berbicara

berpotensi lebih besar menjadi kata pertama yang diucapkan si bayi.

Memahami makna kata yang diucapkan anak pada masa ini tidaklah mudah.Untuk menafsirkan maksud tuturan anak harus diperhatikan aktivitas anak itu dan unsur-unsur non-linguistik lainnya seperti gerak isyarat, ekspresi,dan benda yang ditunjuk si anak.Mengapa begitu?Menurut Tarigan dkk, (1998)ada dua penyebab, yaitu sebagai berikut.

Pertama, bahasa anak masih terbatas sehingga belum memungkinkan mengekspresikan ide atau perasaannya secara lengkap. Keterbatasan berbahasanya diganti dengan ekspresi muka, gerak tubuh, atau unsur-unsur nonverbal lainnya.

Kedua, apa yang diucapkan anak adalah sesuatu yang paling menarik perhatiannya saja. Sehingga, tanpa mengerti konteks ucapan anak, kita akan kesulitan untuk memahami maksud tuturannya.

Walaupun memahami makna kata yang diucapkan anak pada masa ini tidaklah mudah, tetapi komunikasi aktif dengan si anak sangat penting dilakukan. Untuk 
PEDAGOGIKA

Jurnal Ilmu Pendidikan

Volume 9 (Nomor 2) 2018

dapat berbicara, anak perlu peristiwa. Selain itu, anak belum mengetahui perbendaharaan katayang akan disimpan di otaknya dan ini bisa didapat ketika orang tua mengajak bicara. Selain itu, yang perlu diperhatikan dalam menghadapi anak yang memasuki usia ini adalah"jangan memakai bahasa bayi untuk anak-anak, melainkan dengan orang dewasa." Maksudnya, ucapkanlah dengan bahasa yang seharusnya di dengar sehingga si anak juga terpacu untuk berkomunikasi dengan baik.

3) Tahap dua-kata (18 - 24 bulan)

Pada masa ini, kebanyakan anak sudah mulai mencapai tahap kombinasi dua kata. Kata-kata yang diucapkan ketika masih tahap satu kata dikombinasikan dalam ucapanucapan pendek tanpa kata penunjuk, kata depan, atau bentuk-bentuk lain yang seharusnya digunakan. Pada tahap dua kata ini anak mulai mengenal berbagai makna kata tetapi belum dapat menggunakan bentuk bahasa yang menunjukkan jumlah, dapat menggunkan pronomina saya, aku, kamu, dia, mereka, dan sebaginya.

4) Tahap banyak-kata (3 - 5 tahun)

Pada saat anak mencapai usia 3 tahun, anak semakin kaya dengan perbendaharaan kosakata. Mereka sudah mulai mampu membuat kalimat pertanyaan, penyataan negatif, kalimat majemuk, dan berbagai bentuk kalimat. Terkait dengan itu, Tompkins dan Hoskisson dalam Tarigan dkk. (1998) menyatakan bahwa pada usia $3-4$ tahun, tuturan anak mulai lebih panjang dan tatabahasanya lebih teratur. Dia tidak lagi menggunakan hanya dua kata, tetapi tiga atau lebih. Pada umur 5 - 6 tahun, bahasa anak telah menyerupai bahasa orang dewasa.Sebagian besar aturan gramatika telah dikuasainya dan pola bahasa serta panjang tuturannya semakin bervariasi. Anak telah mampu menggunakan bahasa dalam berbagai cara untuk berbagai keperluan, termasuk bercanda atau menghibur. 
Seiring dengan perkembangan bahasa, berkembang pula penguasaan anak-anak atas sistem bahasa yang dipelajarinya. Sistem bahasa itu terdiri atas subsistem, yaitu: fonologi, morfologi, sintaksis, semantik, dan pragmatic.

\section{Perkembangan Fonologis}

Sebelum masuk SD, anak telah menguasai sejumlah fonem/bunyi bahasa, tetapi masih ada beberapa fonem yang masih sulit diucapkan dengan tepat. Menurut Woolfolk (1990) sekitar $10 \%$ anak umur 8 tahun masih mempunyai masalah dengan bunyi $s, z, v$. Hasil penelitian Budiasih dan Zuhdi (1997) menunjukkan bahwa anak kelas dua dan tiga melakukan kesalahan pengucapan $f$, sy, dan $k s$ diucapkan $p$, $s, k$. Terkait dengan itu, Tompkins (1995) juga menyatakan bahwa ada sejumlah bunyi bahasa yang belum diperoleh anak sampai menginjak usia kelas awal SD, khususnya bunyi tengah dan akhir, misalnya $v, z h$, sh,ch. Bahkan pada umur 7 atau 8 tahun anak masih membuat bunyi pengganti pada bunyi konsonan kluster. Kaitannya dengan anak SD di Indonesia diduga pun mengalami kesulitan dalam pengucapan $r, z, v, f$, $k h$, sh, sy, $x$, dan bunyi kluster misalnya $s t r, p r$, pada kata struktur dan pragmatik.

\section{Perkembangan Morfologis}

Afiksasi bahasa Indonesia merupakan salah aspek morfologi yang kompleks. Hal ini terjadi karena satu kata dapat berubah makna karena proses afiksasinya (prefiks, sufiks, simulfiks) berubah-ubah. Zuhdi dan Budiasih (1997) menyatakan bahwa anak-anak mempelajari morfem mula-mula bersifat hapalan. Hal ini kemudian diikuti dengan membuat simpulan secara kasar tentang bentuk dan makna morfem. Akhirnya anak membentuk kaidah. Proses yang rumit ini dimulai pada priode prasekolah dan terus berlangsung sampai pada masa adolesen.

\section{Perkembangan Sintaksis}

Brown dan Harlon (dalam Nurhadi dan Roekhan, 1990) berkesimpulan bahwa kalimat awal anak adalah kalimat sederhana, aktif, 
PEDAGOGIKA

Jurnal Ilmu Pendidikan

Volume 9 (Nomor 2) 2018

afirmatif, dan berorientasi berita. Setelah itu, anak baru menguasai kalimat tanya, dan ingkar. Berikutnya kalimat anak mulai diwarnai dengan kalimat elips, baik pada kalimat berita, tanya, maupun ingkar. Sedangkan menurut hasil pengamatan Brown dan Bellugi terhadap percakapan anak, memberi kesimpulan bahwa ada tiga macam cara yang biasa ditempuh dalam mengembangkan kalimat, yaitu: pengembangan, pengurangan, dan peniruan.

Dilihat dari segi frase, menurut Budiasih dan Zuchdi (1997) bahwa frase verba lebih sulit dikuasai oleh anak SD dibanding dengan frase nomina dan frase lainnya. Kesulitan ini mungkin berkaitan dengan perbedaan bentuk kata kerja yang menyatakan arti berbeda. Misalnya ditulis, menuliskan, ditulisi, dan seterusnya. Dari segi pola kalimat lengkap, anak kelas awal cenderung menggunakan struktur sederhana bila berbicara. Mereka sudah mampu memahami bentuk yang lengkap namun belum dapat memahamai bentuk kompleks seperti kalimat pasif (Wood dalam
Crown, 1992). Menurut Emingran siswa kelas atas SD menggunakan struktur yang lebih kompleks dalam menulis daripada dalam berbicara (Tompkins, 1989).

\section{Perkembangan Semantik}

Selama periode usia sekolah dan dewasa, ada dua jenis penambahan makna kata. Secara horisontal, anak semakin mampu memahami dan dapat menggunakan suatu kata dengan nuansa makna yang agak berbeda secara tepat. Penambahan vertikal berupa penambahan jumlah kata yang dapat dipahami dan digunakan dengan tepat (Owens dalam Budiasih dan Zuchdi, 1997). Menurut Lindfors, perkembangan semantik berlangsung dengan sangat pesat di SD. Kosa kata anak bertambah sekitar 3000 kata per tahun (Tompkins, 1989).

Kemampuan anak kelas rendah SD dalam mendefinisikan kata meningkat dengan dua cara. Pertama, secara konseptual yakni dari definisi berdasar pengalaman individu ke makna yang bersifat sosial atau makna yang dibentukbersama. Kedua, anak 
PEDAGOGIKA

Jurnal Ilmu Pendidikan

Volume 9 (Nomor 2) 2018

bergerak secara sintaksis dari definisi

jalur apa, (6) melalui media apa, (7)

kata-kata lepas kekalimat yang dalam peristiwa apa (Tarigan, 1990). menyatakan hubungan kompleks (Owens, 1992).

Menurut Budiasih dan Zuchdi (1997), anak usia SD sudah mampu mengembangkan bahasa figuratif yang memungkinkan penggunaan bahasa secara kreatif. Bahasa figuratif menggunakan kata secara imajinatif, tidak secara literal atau makna sebenarnya untuk menciptakan kesan emosional. Yang termasuk bahasa figuratif adalah (a) ungkapan, (b)metafora, (c) kiasan, (d) pribahasa.

\section{Perkembangan Pragmatik}

Perkembangan pragmatik atau penggunaan bahasa merupakan hal paling penting dibanding perkembangan aspek bahasa lainnya pada usia SD. Hal inipada usia prasekolah anak belum dilatih menggunakan bahasa secara akurat, sistematis, dan menarik. Berbicara tentang pragmatik ada 7 faktor penentu yang perlu dipahami anak (1) kepada siapa berbicara (2) untuk tujuan apa, (3) dalam konteks apa, (4) dalam situasi apa, (5) dengan $\mathrm{Ke}-7$ faktor penentu komunikasi tersebut berkaitan erat dengan fungsi (penggunaan) bahasa yang dikemukakan olehM.A.K Halliday: instrumental, regulator, interaksional, personal, imajinatif, heuristik, dan informatif.

\section{Faktor-faktor Perkembangan} Bahasa Anak

Secara rinci dapat diidentifikasi sejumlah faktor yang mempengaruhi perkembangan bahasa, yaitu:

a. Kognisi (Proses Memperoleh Pengetahuan). Tinggi rendahnya kemampuan kognisi individu akan mempengaruhi cepat lambatnya perkembangan bahasa individu. Ini relevan dengan pembahasan sebelumnya bahwa terdapat korelasi yang signifikan antara pikiran dengan bahasa seseorang.

b. Pola Komunikasi Dalam Keluarga. Dalam suatu keluarga yang pola komunikasinya banyak arah akan mempercepat perkembangan bahasa keluarganya. 
c. Jumlah Anak Atau Jumlah Keluarga. Suatu keluarga yang memiliki banyak anggota keluarga, perkembangan bahasa anak lebih cepat, karena terjadi komunikasi yang bervariasi dibandingkan dengan yang hanya memiliki anak tunggal dan tidak ada anggota lain selain keluarga inti.

d. Posisi Urutan Kelahiran. Perkembangan bahasa anak yang posisi kelahirannya di tengah akan lebih cepat ketimbang anak sulung atau anak bungsu. Hal ini disebabkan anak sulung memiliki arah komunikasi ke bawah saja dan anak bungsu hanya memiliki arah komunikasi ke atas saja.

e. Kedwibahasaan (Pemakaian dua bahasa). Anak yang dibesarkan dalam keluarga yang menggunakan bahasa lebih dari satu atau lebih bagus dan lebih cepat perkembangan bahasanya ketimbang yang hanya menggunakan satu bahasa saja karena anak terbiasa menggunakan bahasa secara bervariasi. Misalnya, di dalam rumah dia menggunakan bahasa sunda dan di luar rumah dia menggunakan bahasa Indonesia.

Dalam bukunya "Psikologi Perkembangan Anak dan Remaja" Syamsu Yusuf mengatakan bahwa perkembangan bahasa dipengaruhi oleh 5 faktor, yaitu: faktor kesehatan, intelegensi, statsus sosial ekonomi, jenis kelamin, dan hubungan keluarga.

\section{Hambatan \\ Bahasa Anak}

\section{Perkembangan}

Keterlambatan berbicara tidak hanya mempengaruhi penyesuaian akademis dan pribadi anak, pengaruh yang paling serius adalah terhadap kemampuan membaca pada awal anak masuk sekolah.Banyak penyebab keterlambatan bicara pada anak.Salah satu penyebab tidak diragukan lagi paling umum dan paling serius adalah ketidakmampuan

mendorong/memotivasi anak berbicara, bahkan pada saat anak mulai berceloteh. Apabila anak tidak diberikan rangsangan (stimulasi) didorong untuk berceloteh, hal ini akan menghambat penggunaan 
didalam berbahasa/kosa kata yang baik dan benar.

Kekurangan dorongan tersebut merupakan penyebab serius keterlambatan berbicara anak. Anakanak dari golongan yang lebih atau menengah yang orang tuanya ingin sekali menyuruh mereka (anak) belajar berbicara lebih awal (cepat) dan lebih baik, sangat kurang kemungkinannya mengalami keterlambatan berbicara pada anak.Sedangkan anak yang berasal dari golongan yang lebih rendah yang orang tuanya tidak mampu memberikan dorongan tersebut bagi mereka, apakah kekurangan waktu/karena mereka tidak menyadari betapa pentingnya suatu perkembangan bicara pada anak didik tersebut.

Gangguan/bahaya didalam perkembangan bicara pada anak yaitu :

1. Kelemahan didalam berbicara (berbahasa) kosa kata,

2. Lamban mengembangkan suatu bahasa/didalam berbicara,

3. Sering kali berbicara yang tidak teratur,
4. Tidak konsentrasi didalam menerima suatu kata (bahasa) dari orang tua/guru.

Perkembangan berbicara merupakan suatu proses yang sangat sulit dan rumit. Terdapat beberapa kendala yang sering kali dialami oleh anak, antara lain: 1. Anak cengeng.

Anak yang sering kali menangis dengan berlebihan dapat menimbulkan gangguan pada fisik maupun psikis anak. Dari segi fisik, gangguan tersebut dapat berupa kurangnya energi sehingga secara otomatis dapat menyebabkan kondisi anak tidak fit. Sedangkan gangguan psikis yang muncul adalah perasaan ditolak atau tidak dicintai oleh orang tuanya, atau anggota kcluarga lain. Sedangkan reaksi sosial terhadap tangisan anak biasanya bernada negatif. Oleh karena itu peranan orang tua sangat penting untuk menanggulangi hal tersebut, salah satu cara untuk mengajarkan komunikasi yang efektif bagi anak.

2. Anak sulit memahami isi pembicaraan orang lain.

Sering kali anak tidak dapat memahami isi pembicaraan orang tua atau anggota keluarga lain. Hal ini 
PEDAGOGIKA

Jurnal Ilmu Pendidikan

Volume 9 (Nomor 2) 2018

disebabknn kurangnya

bertahap. Tahapan dalam

perbendaharaan kata pada anak. Di

perkembangan anak ada 4 tahap,

samping itu juga dikarenakan orang

yaitu : tahap pralinguistik, tahap satu

tua sering kali berbicara sangat cepat

kata, tahap dua kata, tahap banyak

dengan mempergunakan kata-kata

yang belum dikenal oleh anak. Bagi

kata. Seiring dengan perkembangan

bahasa, berkembang pula penguasaan

keluarga yang menggunakan dua

bahasa (bilingual) anak akan lebih

banyak mengalami kesulitan untuk

memahami pembicaraan orang

tuanya atau saudaranya yang tinggal

dalam satu rumah. Orang tua

hendaknya selalu berusaha mencari

penyebab kesulitan anak dalam

memahami pembicaraan tersebut

agar dapat memperbaiki atau

membetulkan apabila anak kurang

mengerti dan bahkan salah

mengintepretasikan suatu

pembicaraan.

\section{C.KESIMPULAN}

Perkembangan bahasa pada anak usia dini sangat penting karena dengan bahasa sebagai dasar kemampuan seorang anak akan dapat meningkatkan kemampuankemampuan yang lain. Kemampuan berbahasa anak tidak diperoleh secara tiba-tiba atau sekaligus, tetapi anak-anak atas sistem bahasa yang dipelajarinya. Sistem bahasa itu terdiri atas subsistem, yaitu: fonologi, morfologi, sintaksis, semantik, dan pragmatik. Adapaun faktor-faktor yang mempengaruhi perkembangan bahasa adalah : kognisi, pola komunikasi dalam keluarga, jumlah anak, posisi urutan kelahiran, kedwibahasaan.

Bagi seorang guru/orang tua sebaiknya lebih memperhatikan anak-anak usia dini didalam berbicara dengan baik, karena berbicara yang baik untuk diajari kepada anak sangatlah susah didalam menyebutkan kosa kata/pengucapan dengan sempurna kepada anak didalam perkembangan bicara.

Pendidik perlu menerapkan ide-ide yang dimilikinya untuk mengembangkan kemampuan berbahasa anak, memberikan contoh penggunaan bahasa dengan benar, menstimulasi perkembangan bahasa 
PEDAGOGIKA

Jurnal Ilmu Pendidikan

Volume 9 (Nomor 2) 2018

anak dengan berkomunikasi secara

http://www.sekolahrumah.com/index aktif. Anak terus perlu dilatih untuk berpikir dan menyelesaikan masalah melalui bahasa yang dimilikinya. Kegiatan nyata yang diperkuat dengan komunikasi akan terus meningkatkan kemampuan bahasa anak. Lebih daripada itu, anak harus ditempatkan di posisi yang terutama, sebagai pusat pembelajaran yang .php?option=com_content\&task=vie $\underline{w} \& \mathrm{id}=1030 \&$ Itemid $=209$

Massofa. Perkembangan Bahasa Anak.

http://massofa.wordpress.com/2008/0 4/29/perkembangan-bahasa-anak/.

Diakses tanggal 8 november 2017

https://silmyizati.blogspot.co.id/2013 /06/makalah-perkembangan-bahasaanak.html. Diakses tanggal 8 november 2017

perlu dikembangkan potensinya.

\section{REFERENSI}

Dworwtzky, John P. 1990.

Introduction to Child Development.

New York: West

Publishing Company.

Tarigan dkk., Djago dkk. 1998.

Pendidikan Bahasa dan Sastra

Indonesia di

Kelas Rendah. Jakarta:

Depdikbud.

Zuchdi, Darmiati dan Budiasih.

1997. Pendidikan Bahasa dan Sastra

Indonesia

di Kelas Rendah. Jakarta:

Depdikbud.

Owens, R.E. 1992. Language

Development an Introduction. New

York:

Macmillan Publising

Company. 